\title{
The important risk-taking of advocating for student partnership practice
}

Aimie Brennan, Department of Policy and Practice, Marino Institute of Education, Ireland

Contact: aimie.brennan@mie.ie

As a lecturer in teacher education in an Irish higher education institution, I have always believed in the value of student voice and drawing on lived experience, but I never set out to be a champion of learner-teacher partnership practices. Like many others, I was concerned about student engagement in my classes, and I knew the way forward was to invite students into a dynamic participatory process where we would learn and create together. What I had not anticipated was that push back from academic peers would compel me into being a "reluctant advocate" for partnership practice. I use the term "reluctant advocate" not because I don't believe in Students as Partners, but because it is hard being vulnerable and sharing your philosophical stance when it challenges the status quo. By sharing my lived experience now, I highlight some of the considerations facing teachers who are resisting the "how we do things" pressures that reproduce existing learner-teacher power structures and cause tensions between colleagues. This is a call to action for all higher education teachers engaged in partnership practice to consider themselves advocates, reluctant or willing, for partnership values in the face of strong cultural norms that privilege existing learner-teacher hierarchies and product over process. I argue that without teachers as drivers of a process-over-product approach to education, partnership practice will remain an idealised goal experienced by few.

\section{INQUIRY AND RESEARCH WITH STUDENTS}

Three years ago, I invited students to work with me on designing and developing a project that would increase student teachers' engagement with research methods during initial teacher education. The goal of the project was to respond to students' needs, to support them as budding researchers, and to increase their engagement with the practical application of research in the classroom. I worked with students on what ultimately became the Student Teacher Educational Research project, sharing and publishing student education research in Ireland (Brennan, 2019). The project has been lucky enough to receive continued support since its inception, but as the project grows, the power of "how we do things" sometimes calls into question the process of partnership therein.

\section{RESISTING THE FOCUS ON OUTPUTS AND OWNERSHIP THAT DIMINISH STUDENT PARTICIPATION \\ When originally adopting a partnership approach, I had not anticipated how} challenging it would be to ensure the integrity of students' input and to protect our shared ethos. Some colleagues and policymakers felt that predetermined decisions (made by 
teachers) were necessary to move student-teacher projects forward and that relying on student volunteers was too risky. These views position students as one homogenous group and sometimes felt reflective of discourse on marketization of education where students have "too much power." For me it was important to make sense of, rather than dismiss, students' position. I found that understanding their position was made easier through informal, often task-oriented dialogue. Through sharing responsibility for tasks and making collaborative decisions, students and teachers listened, considered and compromised. The outcome was a shared vision for the project in which all members were collectively invested. The most significant learning from the project derived from this process of working in partnership with students, yet attention and recognition from colleagues tends to focus on the outputs of that partnership. The issue with recognising product over process is that it fails to promote learner-teacher practices where students have the most power and input. As a counterbalance, I have focused much of my writing and presentations about the project on the process of partnership and have shared our model with interested organisations and colleagues in the hope that it will be adapted by new partnership projects. However, shifting the status quo is tricky and troublesome, as many scholars have noted (Lygo-Baker, 2019; Bovill et al., 2016). I continue to initiate conversation and research on the value, ethos and ethic of partnership practices to ensure dominant narratives are challenged.

\section{SO WHY A RELUCTANT ADVOCATE RATHER THAN A CHAMPION?}

- Partnership does not have widespread support because it challenges the status quo in learner-teacher power relationships and brings with it a degree of risk for teacher partners (Grace, 1995). Highlighting the misconceptions or misinterpretations of partnership can feel like criticising colleagues and institutions who are working hard in other ways to support students. Finding a way to constructively challenge misconceptions is essential.

- Talking about and writing about partnership means starting a conversation about a personal journey, a value system, and a philosophy. This can be uncomfortable for academics who are used to writing themselves out of their work. Embracing value conversations is helpful to teachers who find themselves facing tensions, misconceptions, and/or uncertainty in relation to partnership.

- By introducing student partnership into the teaching and learning vernacular we have to acknowledge that we are asking people to think differently, to approach practice differently (Matthews, 2019). Teachers who may be slower to adapt need support from advocates to ask questions, voice concerns, and seek help to adapt their practice. Respectful dialogue should be initiated by advocates.

- Promoting a partnership approach when seeking funding is difficult because it can mean committing to pre-determined outputs, numbers of participants, or deadlines that may not materialise until students are engaged in partnership. Therefore partnerships often start without funding and require a degree of risk. Teacher 
partners need support from institutions and leaders who understand the professional risk associated with partnership practice, but they too must take responsibility for highlighting these risks to colleagues.

- Addressing the concerns and questions of colleagues in a measured and appropriate manner requires partners to be able to articulate their approach to partnership, but this is not easy. It took significant engagement with scholarship and reflection before discerning my approach to partnership. Admitting the complexity of partnership as a concept is important when encouraging teachers to engage.

There are wonderful groups, projects and initiatives in Ireland and abroad that help teachers to embrace a partnership approach to teaching and learning in higher education. Yet, as my lived experience signals, few teachers have first-hand experience of engaging in meaningful partnerships with students. It is incumbent upon those of us who are practicing student-partnership in academic departments without an ethos of partnership (which are far greater than those with such a culture) to resist the "how we do things" pressure that reproduces existing learner-teacher power structures. In doing so, we become advocates, reluctant or willing, who promote and encourage student partnership processes.

\section{ACKNOWLEDGEMENTS}

Thank you to Kelly Matthews for engaging in collegial dialogue and offering insights that enriched this piece. I'd also like to thank all the students and staff volunteers who have supported the work of the Student Teacher Education Research partnership project in Ireland.

\section{NOTE ON CONTRIBUTOR}

Dr Aimie Brennan is a Lecturer in Education Policy and Research at Marino Institute of Education, Dublin, Ireland. She is founding coordinator of the Student Teacher Educational Research (STER) student partnership project and editor of the STER e-journal. Her research and teaching interests are in the areas of teacher research, teacher education policy, and student engagement.

\section{REFERENCES}

Bovill, C., Cook-Sather, A., Felten, P., Millard, L. \& Moore-Cherry, N. (2016). Addressing potential challenges in co-creating learning and teaching: Overcoming resistance, navigating institutional norms and ensuring inclusivity in student-staff partnerships. Higher Education, 71(1), 195-208. https://doi.org/10.1007/s10734-015-9896-4

Brennan, A. (2019). Student teacher educational research (STER): An innovation in Irish teacher education. Education Research and Perspectives: An International Journal, 46(1), 44-74. https://eric.ed.gov/?id=EJ1245540

Grace, G. (1995). School leadership: Beyond education management. An essay in policy scholarship. Falmer Press. 
Lygo-Baker, S. (2019). Valuing uncertainty. In S. Lygo-Baker, I. M. Kinchin, N. E. Winstone, (Eds), Engaging student voices in higher education: Diverse perspectives and expectations in partnership (pp. 245-260). Palgrave Macmillan.

Matthews, K. E. (2019). Rethinking the problem of faculty resistance to engaging with students as partners in learning and teaching in higher education. International Journal for the Scholarship of Teaching and Learning, 13(2), 1-5.

https://doi.org/10.20429/ijsotl.2019.130202 